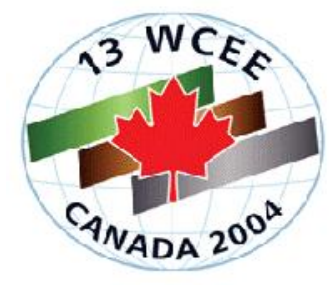

$13^{\text {th }}$ World Conference on Earthquake Engineering

Vancouver, B.C., Canada

August 1-6, 2004

Paper No:270.

\title{
EARTHQUAKE HAZARD IN MARMARA REGION, TURKEY
}

\author{
M. Erdik ${ }^{1}$, M. Demircioglu ${ }^{2}$, K.Sesetyan ${ }^{3}$, E.Durukal ${ }^{4}$ and B.Siyahi ${ }^{5}$
}

\begin{abstract}
SUMMARY
The study develops hazard maps of the Marmara Region depicting peak ground acceleration (PGA) and spectral accelerations (SA)'s at $0.2 \mathrm{~s}$ and $1 \mathrm{~s}$ periods corresponding to $10 \%$ and $2 \%$ probabilities of exceedence in 50 years. Earthquake hazard has been investigated using time-dependent probabilistic (renewal) models.
\end{abstract}

\section{INTRODUCTION}

The strategy used in this study for the assessment of seismic hazard is similar to that used in the preparation of seismic hazard maps for California Frankel [1]. These basic ingredients of the probabilistic hazard assessment are encompassed in the chapters on the regional neo-tectonic setting, regional seismicity, source characterization and the probabilistic hazard assessment methodology.

With the exception of 2 all of the previously published probabilistic assessments of seismic hazard in the Marmara Region were based on simple Poisson Model Erdik [3], Erdik [4], Erdik [5], Jimenez [6], Bommer [7]. Reference Atakan [2] employed time independent and time dependent models for the assessment of hazard quantified in terms of peak ground acceleration associated with a $10 \%$ probability of exceedance in 50 years.

\section{TECTONIC SETTING OF THE MARMARA REGION}

Over the course of history Marmara region in Northwestern Turkey has been the site of numerous destructive earthquakes. Reference Le Pichon [8] developed a fault model based on the data collected in 1997 by the ship "MTA Sismik-1". Data obtained during the recent high-resolution bathymetric survey of the Ifremer RV Le Suroit vessel indicates that a single, thoroughgoing strike-slip fault system (Main Marmara Fault) cuts the Marmara Sea from east to west joining the 17.8.1999 Kocaeli earthquake fault with the 9.8.1912 Sarkoy-Murefte earthquake fault 9 (see Figure 1)

\footnotetext{
${ }^{1}$ Department of Earthquake Engineering, Boğaziçi University, Istanbul, E-mail: erdik@boun.edu.tr ${ }^{2}$ Department of Earthquake Engineering, Boğaziçi University, Istanbul, E-mail: betul.demircioglu@boun.edu.tr

${ }^{3}$ Department of Earthquake Engineering, Boğaziçi University, Istanbul, E-mail: karin@boun.edu.tr

${ }^{4}$ Department of Earthquake Engineering, Boğaziçi University, Istanbul, E-mail: durukal@ boun.edu.tr

${ }^{5}$ Department of Earthquake Engineering, Boğaziçi University, Istanbul, E-mail: bilge.siyahi@boun.edu.tr
} 
Based on recent findings we developed a fault segmentation model for the Marmara Sea region as shown in Figure 2. The segmentation provided relies on the discussion of several portions of the Main Marmara Fault, given in Le Pichon [9], based on bathymetric, sparker and deep-towed seismic reflection data and interprets it in terms of fault segments identifiable for different structural, tectonic and geometrical features. The remaining segments of the model (e.g. for the eastern and southern Marmara regions) are compiled from various studies Barka [10], Saroğlu [11], Akyuz [12] and Yaltirak [13] If seismic creep is neglected, over a long time period, the seismic moment released by earthquakes should balance the seismic moment accumulated by the elastic strain. The inter-event period between large (characteristic) earthquakes in the segments of Main Marmara Fault are also consistently estimated by dividing the seismic slip estimated from the earthquake catalog by the GPS-derived slip rate of $22 \pm 3 \mathrm{~mm} / \mathrm{yr}$. The return periods for the southern segments of the NAF are estimated based on results of GPS measurements and the total offsets provided in Yaltirak [13].

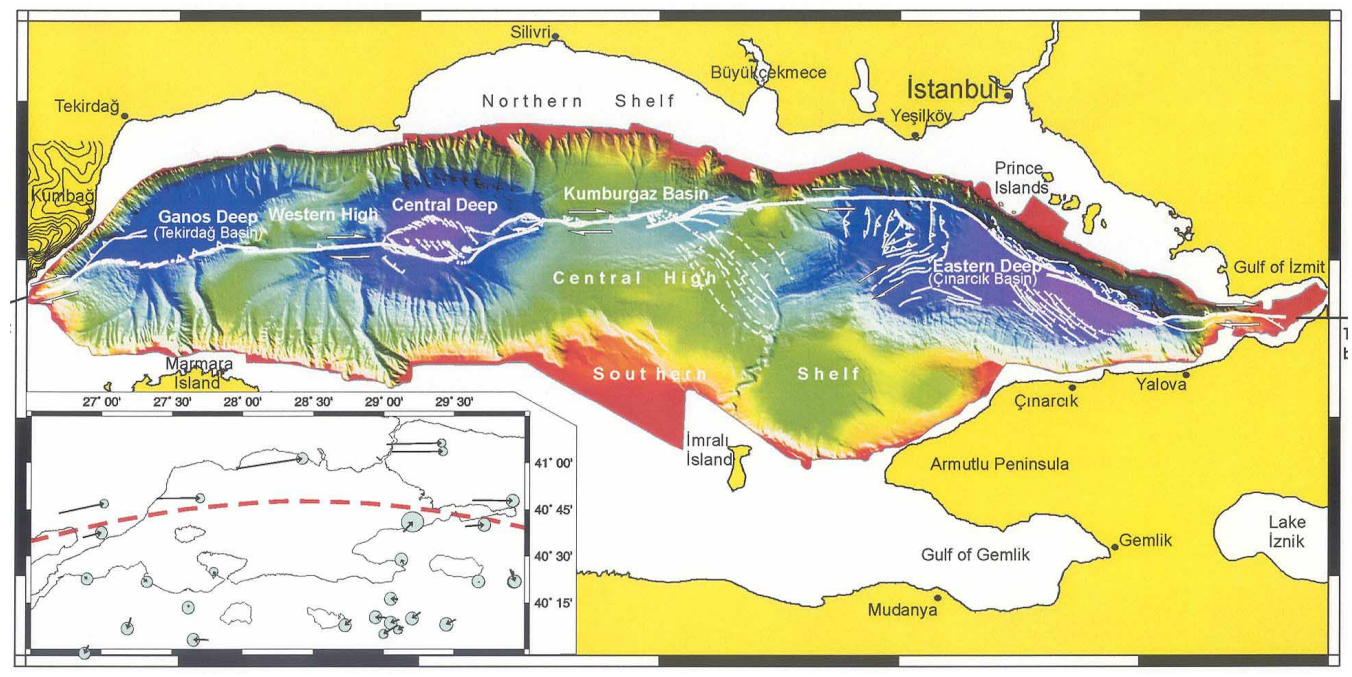

Figure 1. The recent high-resolution bathymetric map obtained from the survey of the Ifremer RV Le Suroit vessel that indicates a single, thoroughgoing strike-slip fault system.

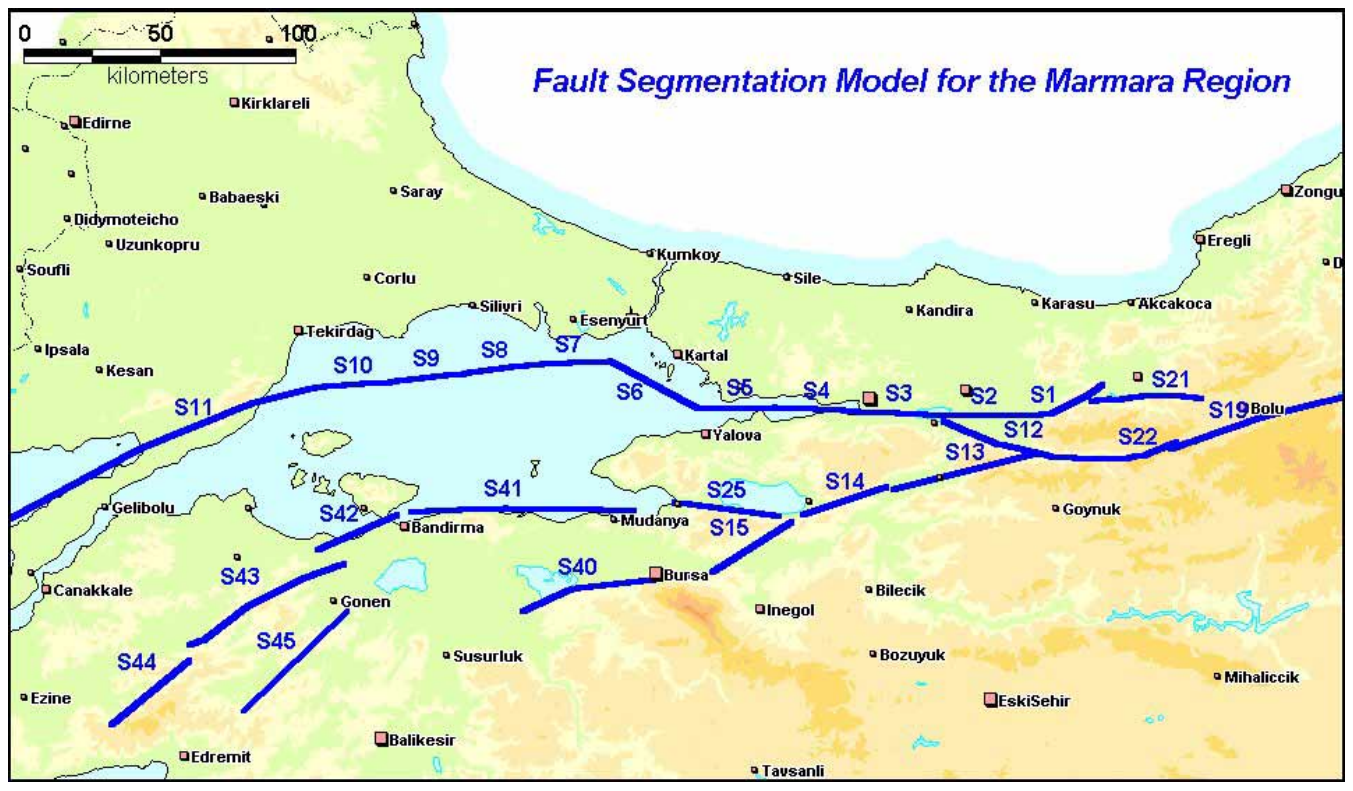

Figure 2. Fault segmentation model proposed for the Marmara region. 


\section{SEISMICITY}

The long-term seismicity of the Marmara region is illustrated in Figure 3. Earthquake records spanning two millennia indicate that, on average, at least one medium intensity ( $\mathrm{Io}=\mathrm{VII}-\mathrm{VIII}$ ) earthquake has affected Istanbul in every 50 years. The average return period for high intensity (Io=VIII-IX) events has been 300 years. The earthquake damage experienced by regional cities as well as by the historical structures in Istanbul has been relatively well documented. It is known that the 1470-year old Hagia Sophia Museum was strongly and repeatedly affected by the earthquakes that took place in the region and was subsequently repaired after every damaging earthquake Durukal [14]. Brief information on the historical earthquakes (with estimated magnitude $\mathrm{Ms} \geq 7.0$ ) of the last two millennia, estimated association with segments and the related damage descriptions are taken from Ambraseys [16] (after 1500).

Recent studies conducted after the 1999 Kocaeli $(\mathrm{Mw}=7.4)$ and Düzce (Mw=7.2) earthquakes indicate (assuming that the stress regime in the Marmara Sea remains unchanged) about 65\% probability for the occurrence of an $\mathrm{Mw}>=7.0$ magnitude earthquake effecting Istanbul Parsons [15]. The association of earthquakes between 1500 to present with the segmentation proposed for the North Anatolian Fault in the Marmara Region is given in Table 1.

In the Marmara region, there exist some potential seismic gaps. For example, along the middle strand from the Mudurnu Valley region to the Aegean Sea there has not been any significant earthquake for the last 400 years, except the 1737 earthquake in the Biga peninsula Ambraseys [16]. The most western portion of the southern strand has not ruptured since 1855. During historical times a number of earthquakes occurred along the northern strand, especially in the Marmara Sea area. Recent seismicity maps indicate a potential seismic gap in the central part of the Marmara Sea Ambraseys [17].

The alignment of the Marmara Fault is clearly evident in Figure 4 and Figure 5, where respectively the epicentral distribution of earthquakes with $\mathrm{M} \geq 3$ from 1.1.1990 to 16.8.1999 (prior to Kocaeli earthquake) and 17.8.1999 to present are illustrated.

Table 1. Association Of Earthquakes Between 1500-Present With The Segmentation Proposed For The North Anatolian Fault In The Marmara Region.

\begin{tabular}{|l|c|}
\hline \multicolumn{1}{|c|}{ Earthquake } & Fault Segment \\
\hline $10.9 .1509(\mathrm{Ms}=7.2)$ & 7,8 \\
\hline $10.5 .1556(\mathrm{Ms}=7.2)$ & 9 \\
\hline $25.5 .1719(\mathrm{Ms}=7.4)$ & $2,3,4,5$ \\
\hline $6.3 .1737(\mathrm{Ms}=7.2)$ & 43 \\
\hline $2.9 .1754(\mathrm{Ms}=6.8)$ & 6 \\
\hline $22.5 .1766(\mathrm{Ms}=7.1)$ & 7,8 \\
\hline $5.8 .1766(\mathrm{Ms}=7.4)$ & 11 \\
\hline $28.2 .1855(\mathrm{Ms}=7.1)$ & 40 \\
\hline $10.7 .1894(\mathrm{Ms}=7.3)$ & $3,4,5$ \\
\hline $9.8 .1912(\mathrm{Ms}=7.3)$ & 11 \\
\hline $1.2 .1944(\mathrm{Ms}=7.3)$ & 19 \\
\hline $18.3 .1953(\mathrm{Ms}=7.2)$ & 45 \\
\hline $26.5 .1957(\mathrm{Ms}=7.0)$ & 22 \\
\hline $22.7 .1967(\mathrm{Ms}=6.8)$ & 12 \\
\hline $17.8 .1999(\mathrm{Mw}=7.4)$ & $1,2,3,4$ \\
\hline $12.11 .1999(\mathrm{Mw}=7.2)$ & 21 \\
\hline
\end{tabular}




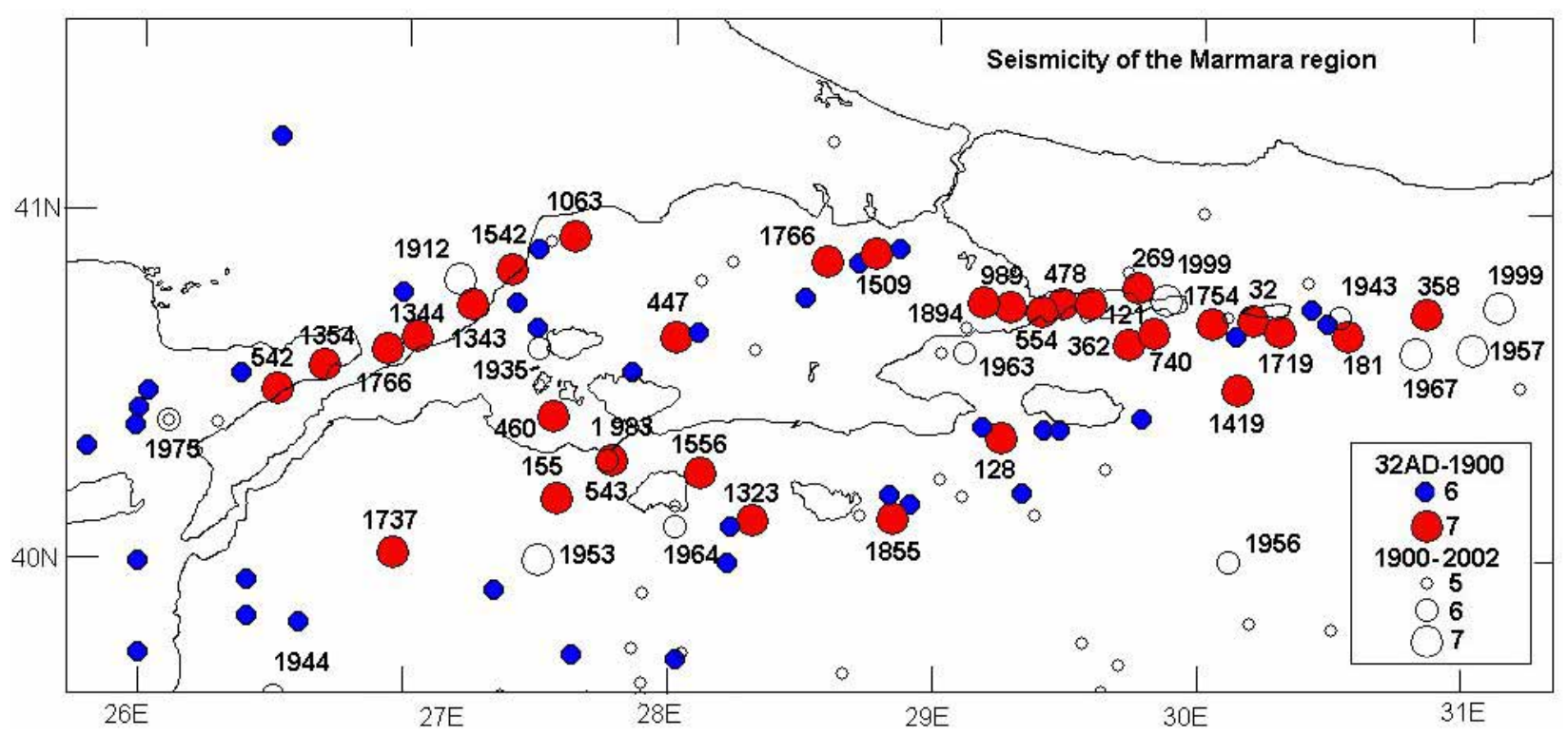

Figure 3. The long-term seismicity of the Marmara region, seismicity between $32 \mathrm{AD}-1983$ taken from Ambraseys [16].

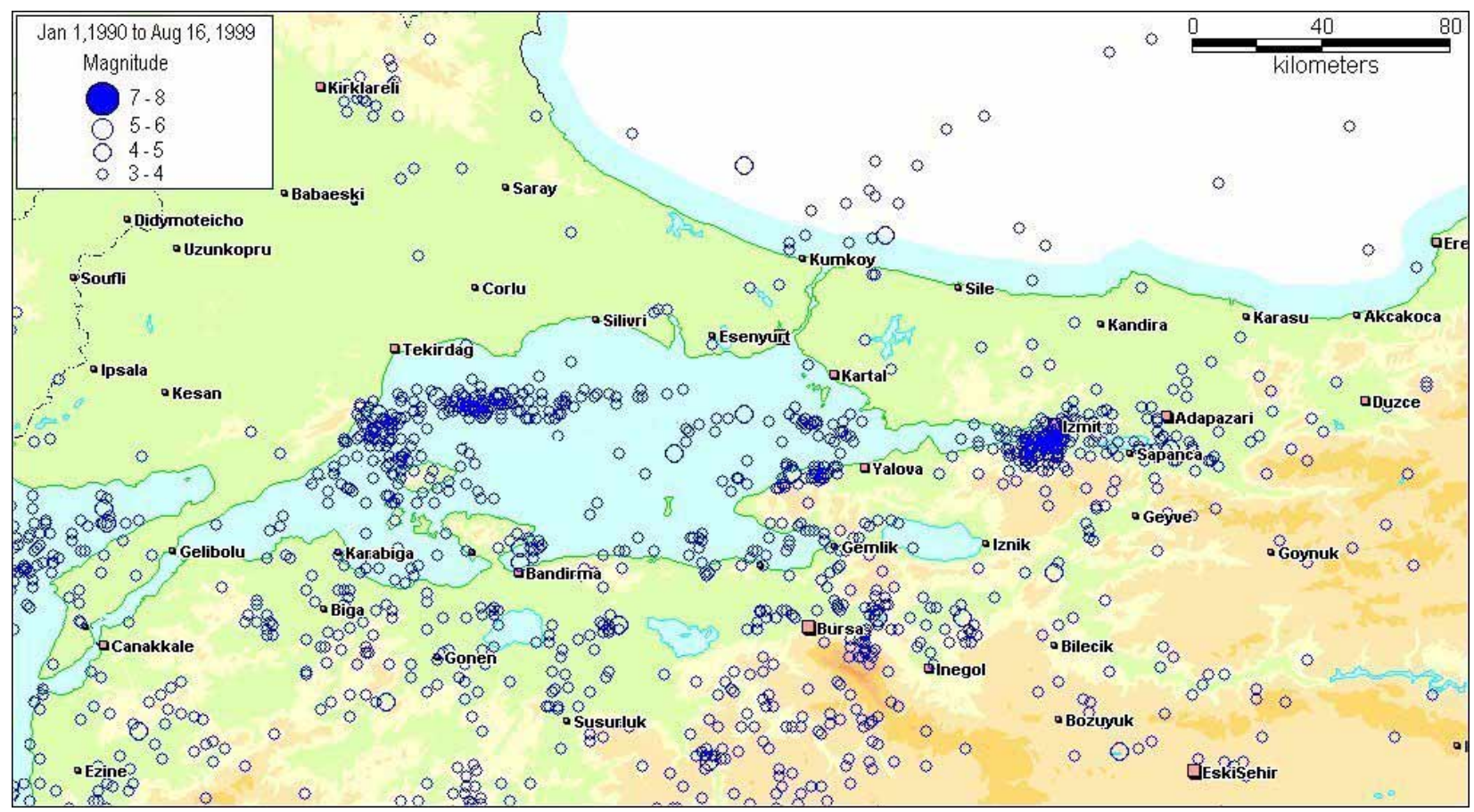

Figure 4. The seismic activity of the Marmara region with $M>3$ events from Jan 1, 1990 to August $16,1999$. 


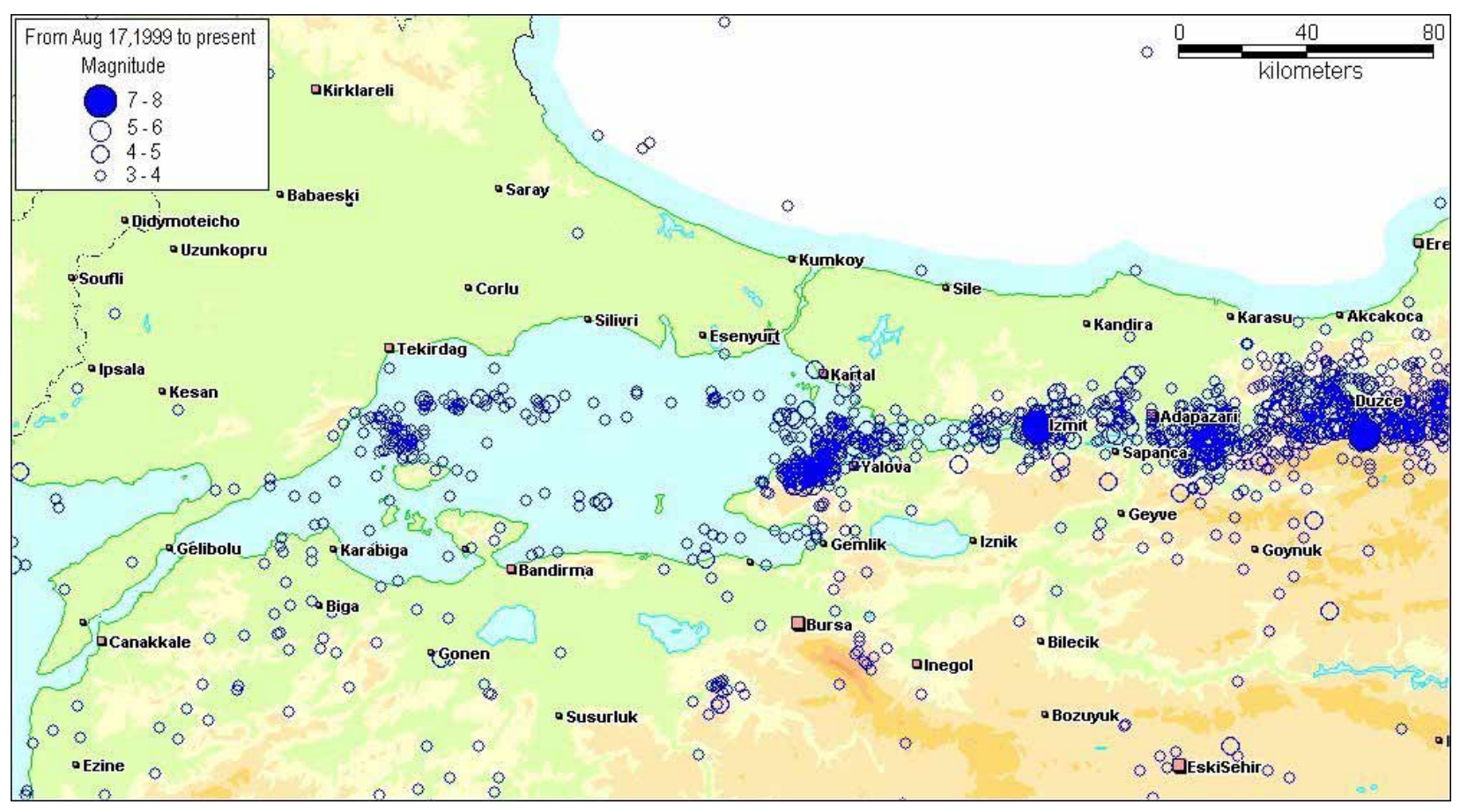

Figure 5. The seismic activity of the Marmara region with $M>3$ events from August 17, 1999 to present.

\section{August 17, 1999 Kocaeli Earthquake}

An earthquake of magnitude Mw 7.4 occurred on the North Anatolian Fault Zone with a macroseismic epicenter near the town of Golcuk (40.702 N, 29.987 E) in the western part of Turkey. Figure 6 illustrates the ruptured fault segments and the fault slip distribution model associated with this earthquake Erdik [18]. The total observable length of the rupture was about $100 \mathrm{~km}$. The lateral offset varied between 1.5 and $5 \mathrm{~m}$. Most of the aftershock activity is confined to the region bounded by $40.5-40.8 \mathrm{~N}$ and $29.8-30.0 \mathrm{E}$, which covers the area between Izmit and Adapazari to the east of the epicenter.

Seismic imaging of the Kocaeli earthquake rupture carried out by Delouis [27] indicates almost pure lateral strike-slip rupture that runs west at a velocity of about $3 \mathrm{~km} / \mathrm{s}$ and towards east at a very high velocity of $4.7 \mathrm{~km} / \mathrm{s}$ for a distance of about $40 \mathrm{~km}$ before dropping to about $3.1 \mathrm{~km} / \mathrm{s}$ at the easternmost segment. The largest slip $7 \mathrm{~m}$ occurs between 25 to $45 \mathrm{~km}$ east of the epicenter. West of the epicenter the slip is large between distances of 10 to $30 \mathrm{~km}$. The rise time is generally between 2 to $4 \mathrm{~s}$. The damage caused by the earthquake covered a very large region extending from Tekirdag to Eskisehir, cities mostly affected being Sakarya, Yalova, Kocaeli, Bolu and Istanbul. The intensively damaged area follows a zone of about $20 \mathrm{~km}$ in width $(10 \mathrm{~km}$ to the north and south of the fault) along the fault rupture. The number of condemned buildings after the earthquakes amounted 23,400. There were 18,373 accounted deaths and 48,901 hospitalized injuries. As much as 120,000 families were left in need of homes after the earthquake. The general isoseismal map of this earthquake is provided in Figure 7 (after Bülent Özmen, General Directorate of Disaster Affairs). The maximum MSK intensity of the Kocaeli earthquake was X, essentially assigned on the basis of fault rupture and excessive ground deformations. 

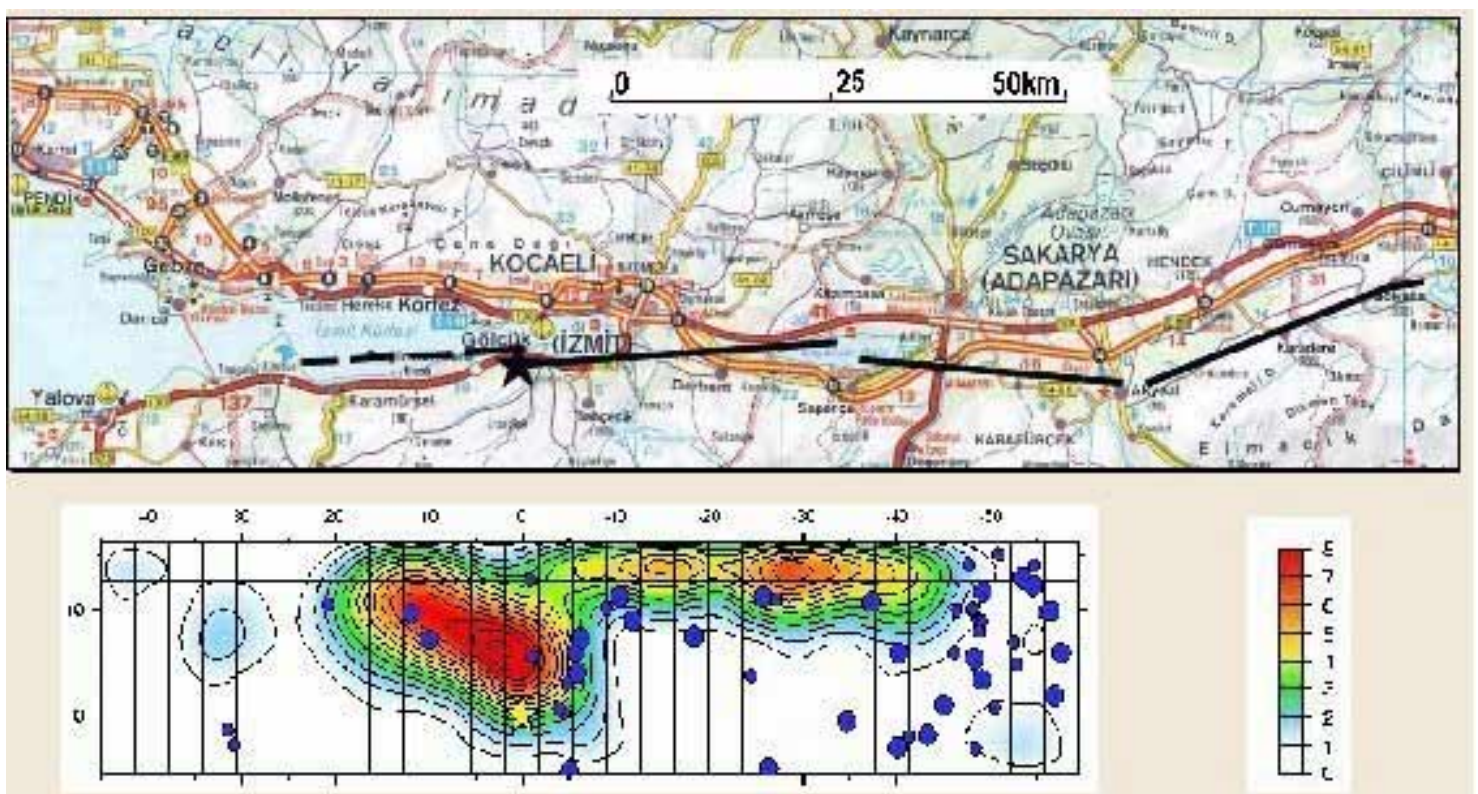

Figure 6. Surface fault ruptures and slip model of the August 17, 1999 Kocaeli earthquake correlated with the Yagi and Kikuchi (1999) rupture model given in Cornell [35], Erdik [18].

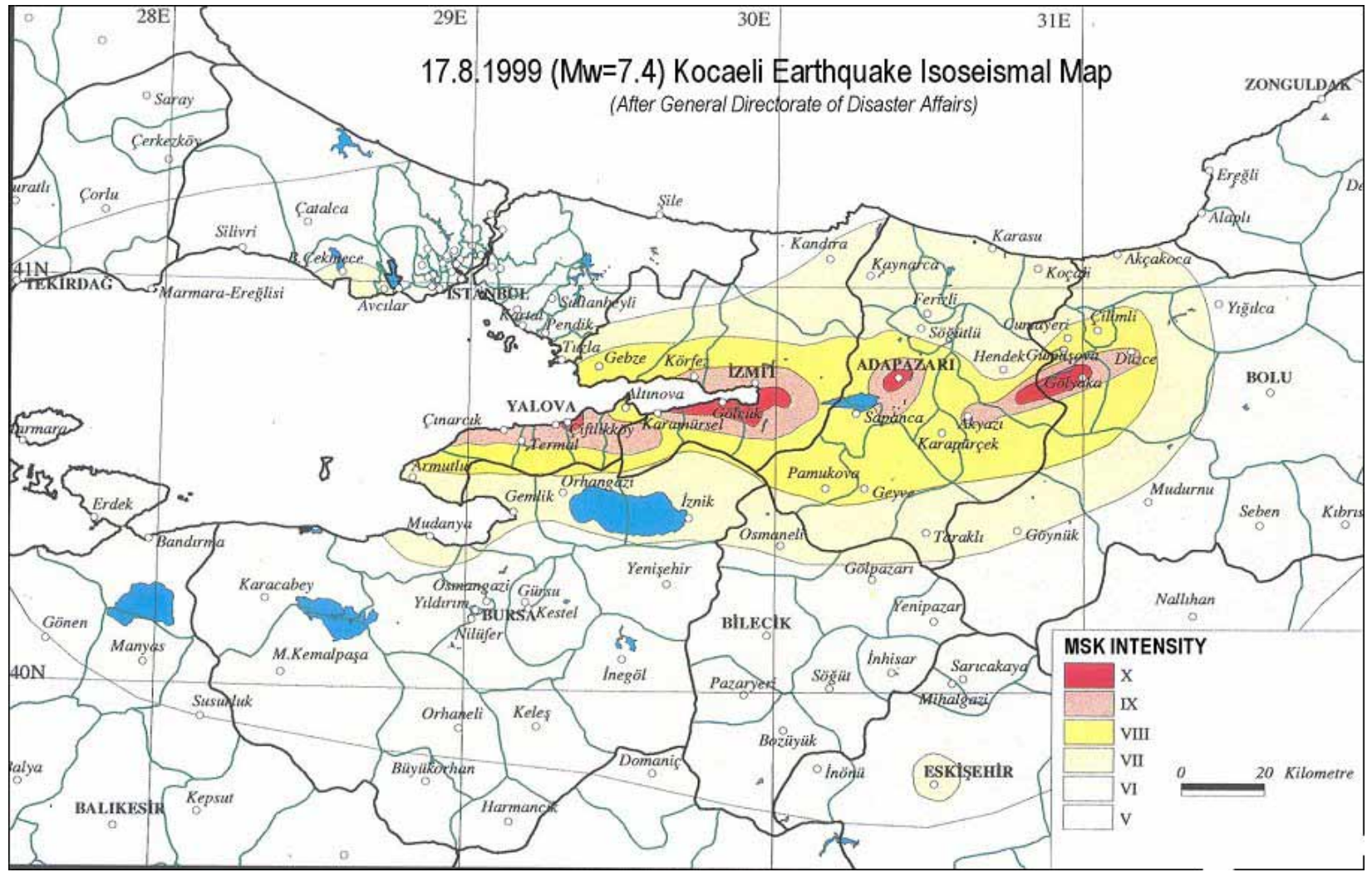

Figure 7. Iso-seismal map of August 17, 1999 Kocaeli earthquake (after B. Ozmen of Gen. Dir. of Disaster Affairs). 


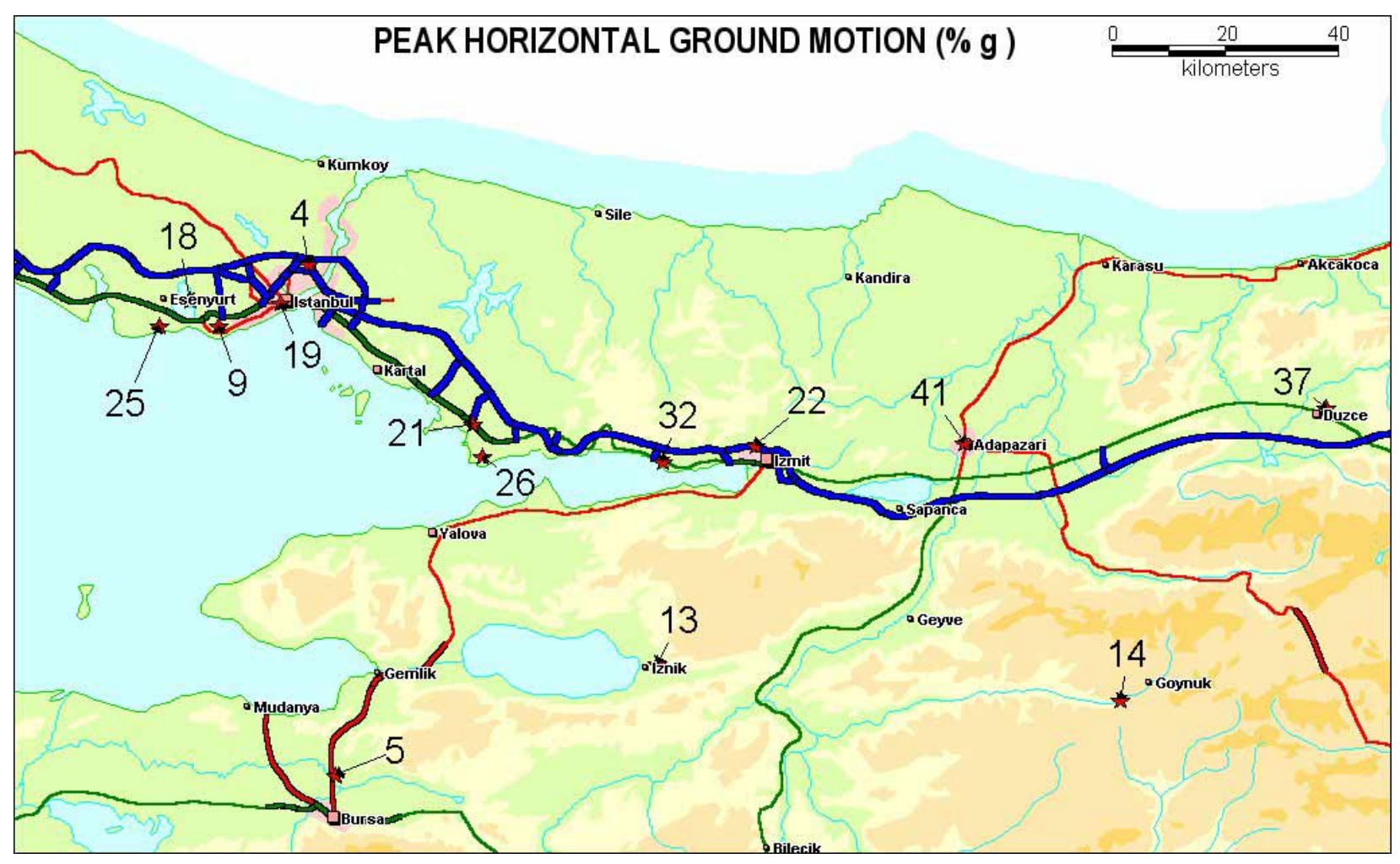

Figure 8. Peak horizontal ground accelerations (as \%g) recorded in the Kocaeli earthquake.

This earthquake is associated with fault segments 1, 2, 3 and 4 (Erdik [18], Yagi [19], Ambraseys [17], Hubert [20]). Location of these segments is shown in Figure 2.

Strong ground motion associated with the Kocaeli earthquake were the subject of several papers such as Rathje[21], Safak [22], Anderson [23], Erdik [24], Durukal [25]. Kocaeli earthquake has generated six motions within $20 \mathrm{~km}$ of the fault (Sakarya, Yarimca, Izmit, Duzce, Arcelik, and Gebze), adding significantly to the near-field database of ground motions for $\mathrm{Mw}>=7.0$ strike-slip earthquakes. The peak ground accelerations recorded at the near fault stations of the earthquake are provided in Figure 8. All of the existing Western U. S. data based attenuation relationships overpredict peak accelerations observed in Kocaeli earthquake at distances less than about $20 \mathrm{~km}$. Reasons for low accelerations may be the smoothness of rupture and the relatively low stress drop in the Kocaeli earthquake The peak velocities are in the order of what has been observed in previous earthquakes of similar nature.

According to Delouis [26] the rupture propagation to the west was relatively homogenous with a rupture velocity of about $3.5 \mathrm{~km} / \mathrm{s}$. To the east, however, the fault within the first $7.5 \mathrm{sec}$ of the process ruptured slower than it did on the west, afterwards accelerating to velocity levels of $3.5 \mathrm{~km} / \mathrm{s}$ and thus contributing to the high amplitude motion observed at Sakarya station (SKR). According to Bouchon [27] the rupture reached the supershear speed of about $4.8 \mathrm{~m} / \mathrm{s}$ at this portion of the fault. Forward directivity may be observed both to the east and west of the fault. As indicated in the source rupture models developed for the earthquake, the directivity effects may have contributed to damage in Yalova and Çınarcık. "Fling" type pulses due to directivity effects are evident in the strong motion data of the Kocaeli earthquake with fling durations in the order of 2-3 sec (Durukal [25]). The Ambarli region to the west of Istanbul recorded unusually large accelerations (above the plus two standard deviation prediction for each attenuation relationship), possibly due to focusing and site effects. 


\section{ATTENUATION RELATIONSHIPS}

The limited strong motion data in Turkey and also in the Eastern Mediterranean region and ambiguities on the station site descriptions does not allow for a comprehensive development of reliable region and site specific ground motion attenuation relationships.

A comparison of the then available Turkish strong motion data with the Western U.S.A data (Joyner [28]) is provided in Erdik [3]. It has been shown that the PGA's recorded in Turkey are safely located within the observed dispersion of the Western U.S.A data. Comparison of the response spectra has been conducted in [30] and in connection with the TEFER [30] project ( Bommer [7]) where it has been indicated that the empirical response spectra of the ground motion at several locations in Turkey can be predicted, within engineering tolerances, by the Western U.S. based attenuation relationships.

On the basis of these favorable predictive comparisons and owing to the geological and geo-tectonic similarity of Anatolia to the California (Strike slip faults similar to North and East Anatolian Faults) and Nevada (Basin and Range region is similar to Aegean Region) we found it to be rational and prudent to utilize, the average of the results obtained from Boore [31], Sadigh [32] and Campbell [33] attenuation relationships for the computation of Peak Ground Acceleration and the average of Boore [31] and Sadigh [32] attenuation relationships for the computation of Spectral Accelerations at $0.2 \mathrm{~s}$ and $1 \mathrm{~s}$ (Ss and S1). Same attenuation relationships have been used for the assessment of earthquake hazard for the Western US Leyendecker [34].

\section{EARTHQUAKE HAZARD}

The basic ingredients of Probabilistic Seismic Hazard Assessment (PSHA) are the definition of earthquake source(s), earthquake occurrences characteristics for each source, ground motion attenuation relationships. This information is numerically integrated using a probabilistic model to obtain the probability of exceedance of different ground motion parameters in a given region Cornell [35], GSHAP [36], Frankel [1].

For tectonic entities that lack information for time-dependent modeling or for large regional seismic sources, time -independent models, such as homogenous Poisson process, can be used.

The use of a time-dependent probabilistic seismic-hazard model is needed for the assessment of probabilistic hazard in the Marmara region. This model is characterized by the recurrence-interval probability-density function of the characteristic earthquakes.

In this study, the aleatory uncertainty is considered by the incorporation of the standard deviation of the log-normally distributed ground motion attenuation relationships. This serves to increase the median hazard. Epistemic uncertainty is accounted by using a logic tree approach in the incorporation of applicable aground motion attenuation relationships.

The earthquake hazard in the region is assumed to be the result of the contributions, computed in following two steps:

(1) Ground motions that would result from the earthquakes in the magnitude range from 5.0 to 6.9 .

(2) Ground motion that would result from larger events in the magnitude range 7.0 and higher.

In Step (1) the undelineated fault sources and small areal sources based on spatially-smoothed historic seismicity are used as the background earthquake source. In this study, spatially-smoothed seismicity was 
considered to assess the background hazard in lieu of areal sources to remove the subjectivity in the delineation of areal sources. This approach also removes the spatially uniform hazard rate in the areal source Perkins [37]. An earthquake catalog of magnitude 5.0 and higher events are used. This catalog is considered to be complete since 1900 for magnitudes greater than 5.5 and since 1940 for magnitudes greater than 5.0. These events are assigned to cells of a grid $\left(0.05^{\circ} \mathrm{x} 0.05\right)$. It is also assumed that a Gutenberg-Richter type recurrence relationship governs the earthquake recurrence in these background sources. The overall $\mathrm{b}$ value for the study area is calculated to be 0.8 by the modified maximum likelihood method proposed by Weichert [38]. The gridded "a" values are spatially smoothed using a twodimensional Gaussian filter with a decay distance of $50 \mathrm{~km}$.

Step (2) is related to the seismic energy release along well-defined and segmented faults. It is assumed that energy along these faults are released by characteristic events identified by magnitude and recurrence time. The relationship between magnitude and length for strike-slip faults provided in Wells [39] is used in this study. The historical seismicity, the tectonic models and the known slip rates along the faults constituted the main data used in the assignment of the recurrence time.

\section{The Time-Dependent (Renewal) Model}

The time dependent model is based on the assumption that the occurrence of large (characteristic) earthquakes has some periodicity. The conditional probability that an earthquake occurs in the next $\Delta \mathrm{T}$ years, given that it has not occurred in the last $\mathrm{T}$ years is given by:

$$
P(T, \Delta T)=\frac{\int_{T}^{T+\Delta T} f(t) d t}{\int_{T}^{\infty} f(t) d t}
$$

where $f(t)$ is the probability density function for the earthquake recurrence intervals, $T$ is the elapsed time since the last major earthquake and $\Delta T$ is the exposure period (taken as 50 years). For the computation of the probability density function a lognormal distribution with a covariance of 0.5 is assumed to represent the earthquake probability density distribution. The 50 year conditional probabilities thus calculated are converted to effective Poissonian annual probabilities by the use of the following expression WGCEP94 [40]:

$\mathbf{R}_{\text {eff }}=-\ln \left(\mathbf{1}-\mathbf{P}_{\text {cond }}\right) / \mathbf{T}$

For regional hazard maps it becomes essential to quantify seismic hazard on the same ground condition so-called "reference ground" from which the ground motion on other types of soils can be inferred or assessed. In this study NEHRP B/C Boundary (characterized with a 30m average shear wave propagation velocity of $760 \mathrm{~m} / \mathrm{s}$ ) is used as the "reference ground" similar to the seismic hazard maps prepared by USGS.

The results obtained for $10 \%$ and $2 \%$ probabilities of exceedence in 50 years for PGA and SA at 0.2 sec and $1.0 \mathrm{sec}$. natural periods at NEHRP B/C boundary site class for the renewal models are presented in Figure 9 through Figure 14. 


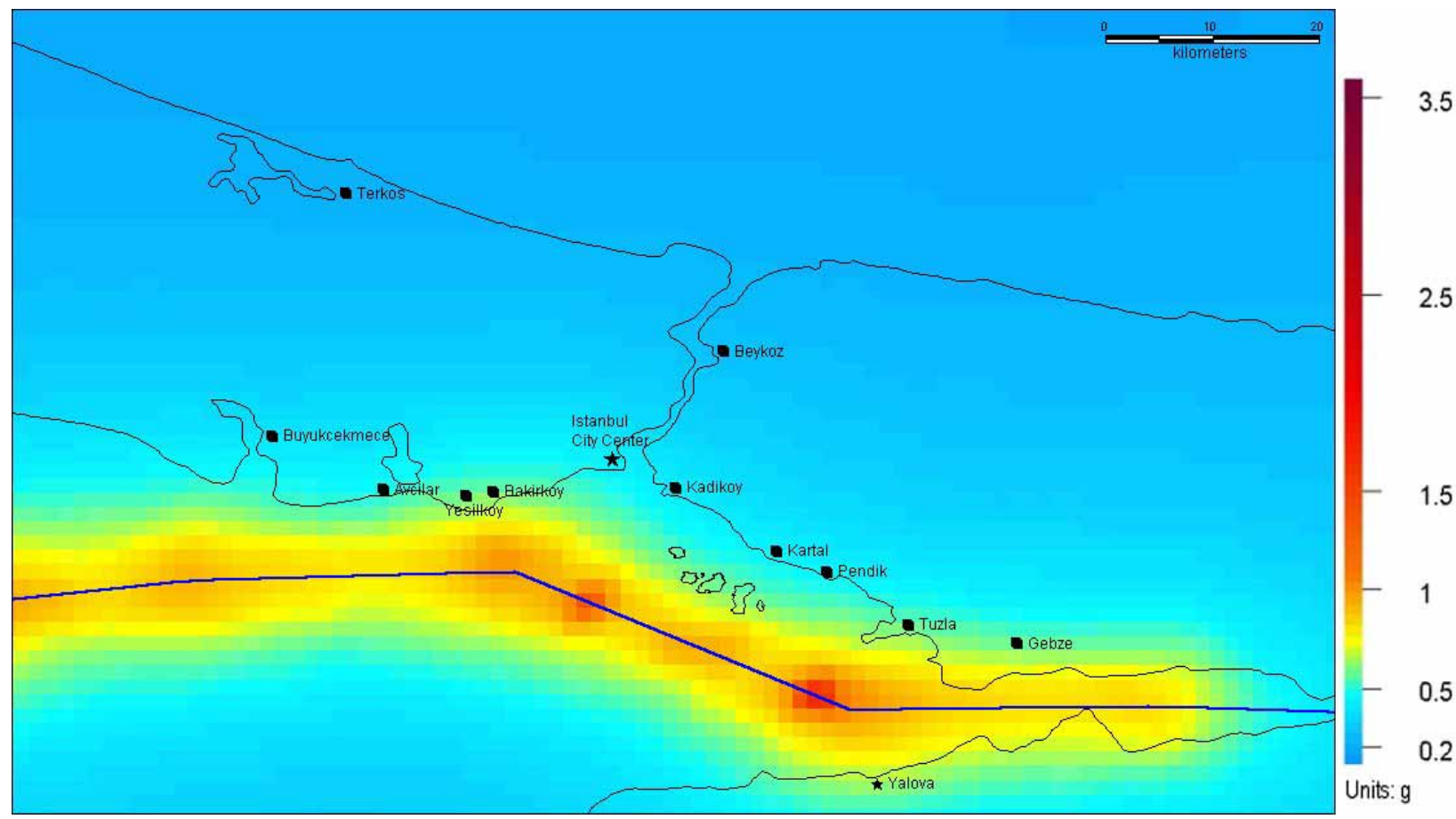

Figure 9. PGA contour map at NEHRP B/C boundary site class for $10 \%$ probability of exceedence in 50 years (Renewal model).

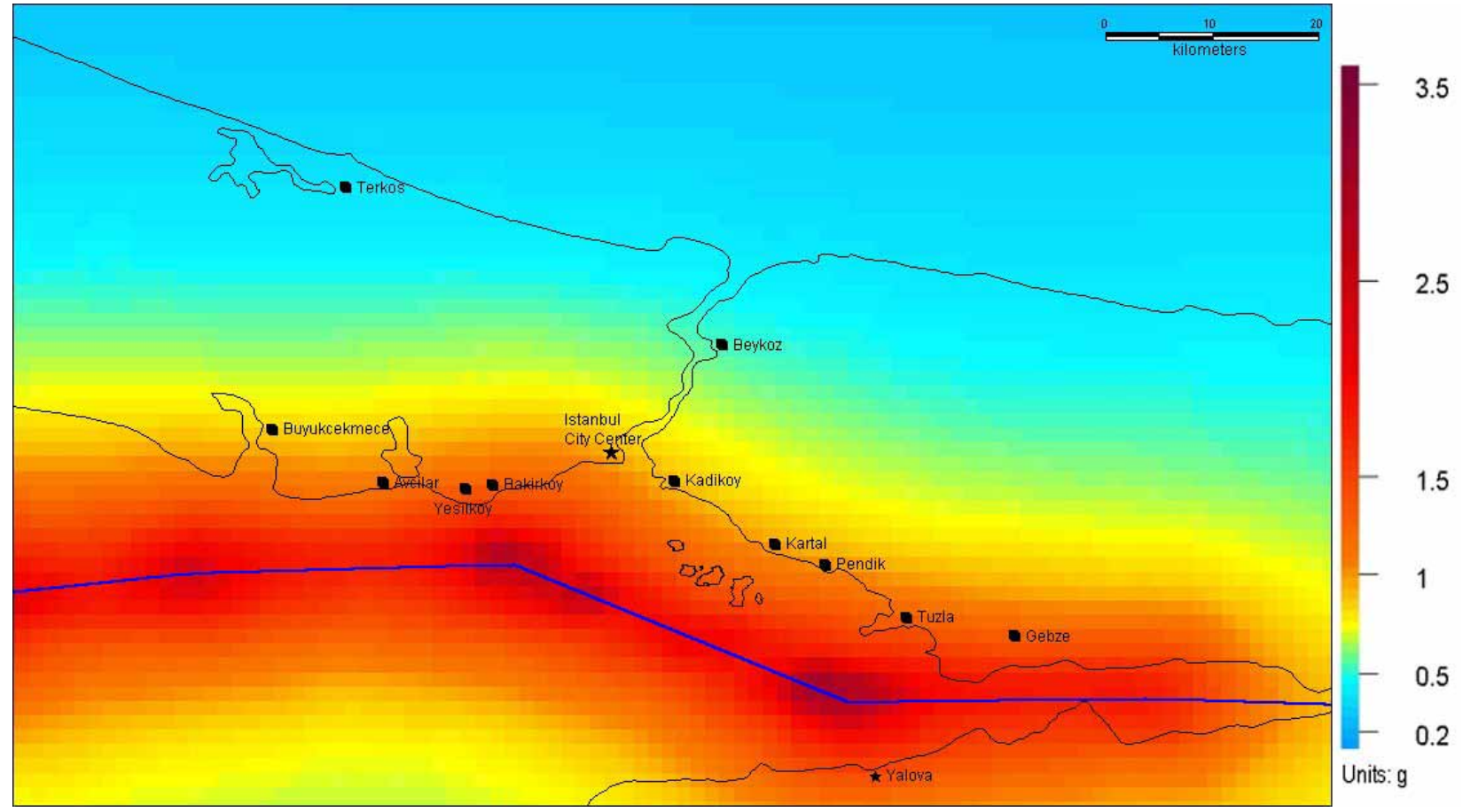

Figure 10. SA $(T=0.2 \mathrm{sec})$ contour map at NEHRP B/C boundary site class for $10 \%$ probability of exceedence in 50 years (Renewal model). 


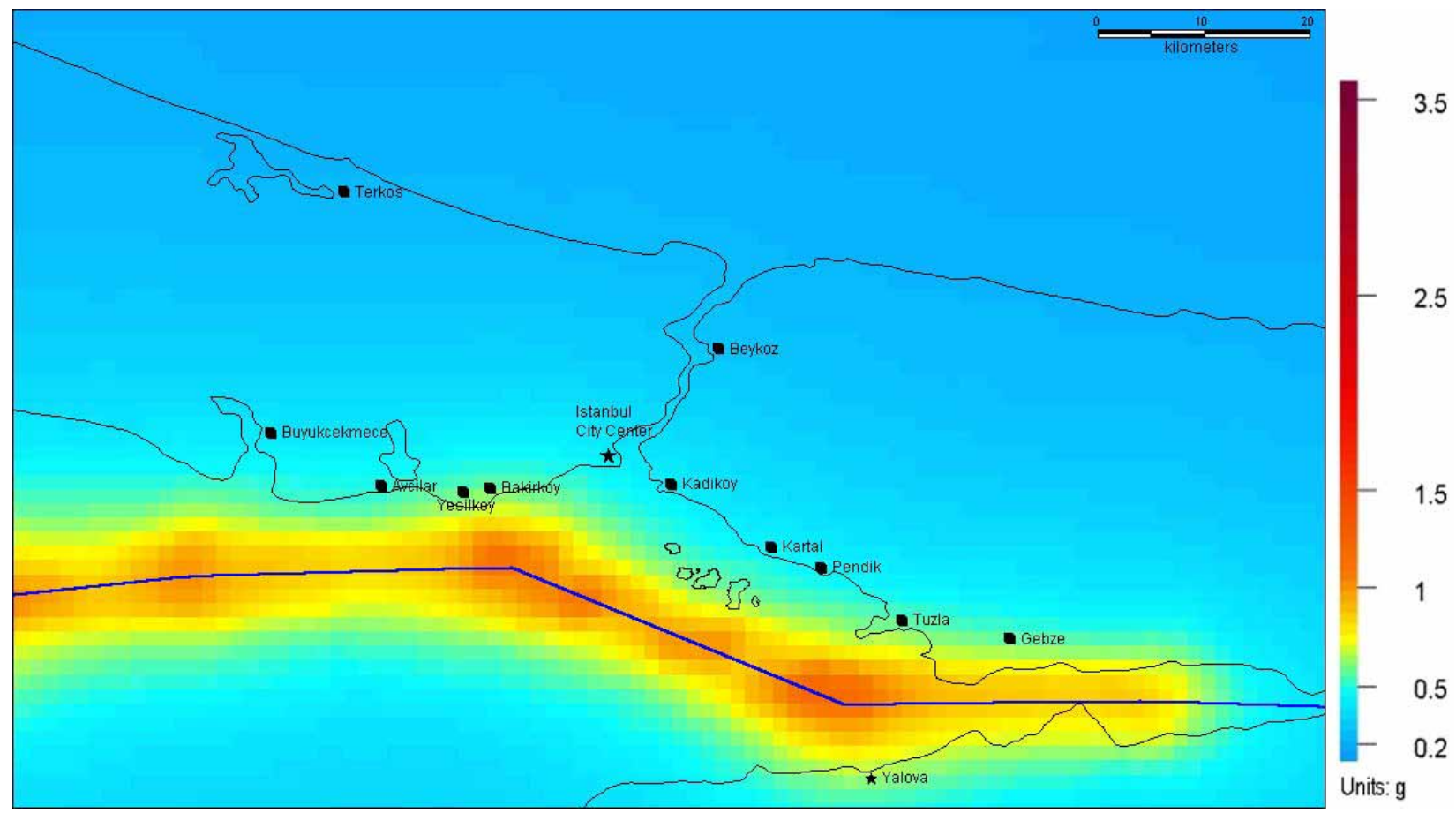

Figure 11. SA $(T=1.0)$ contour map at NEHRP B/C boundary site class for $10 \%$ probability of exceedence in 50 years (Renewal model).

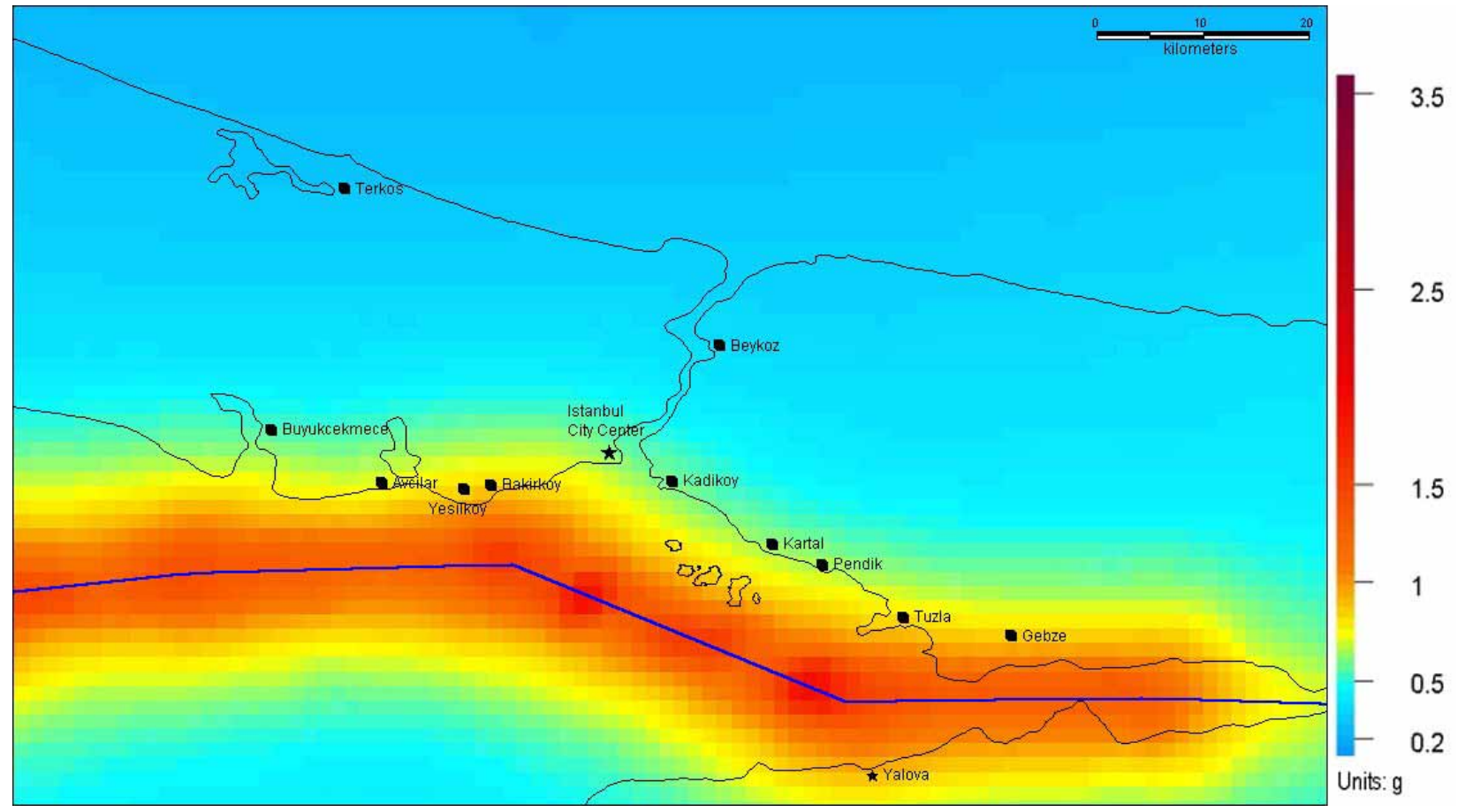

Figure 12. PGA contour map at NEHRP B/C boundary site class for $2 \%$ probability of exceedence in 50 years (Renewal model). 


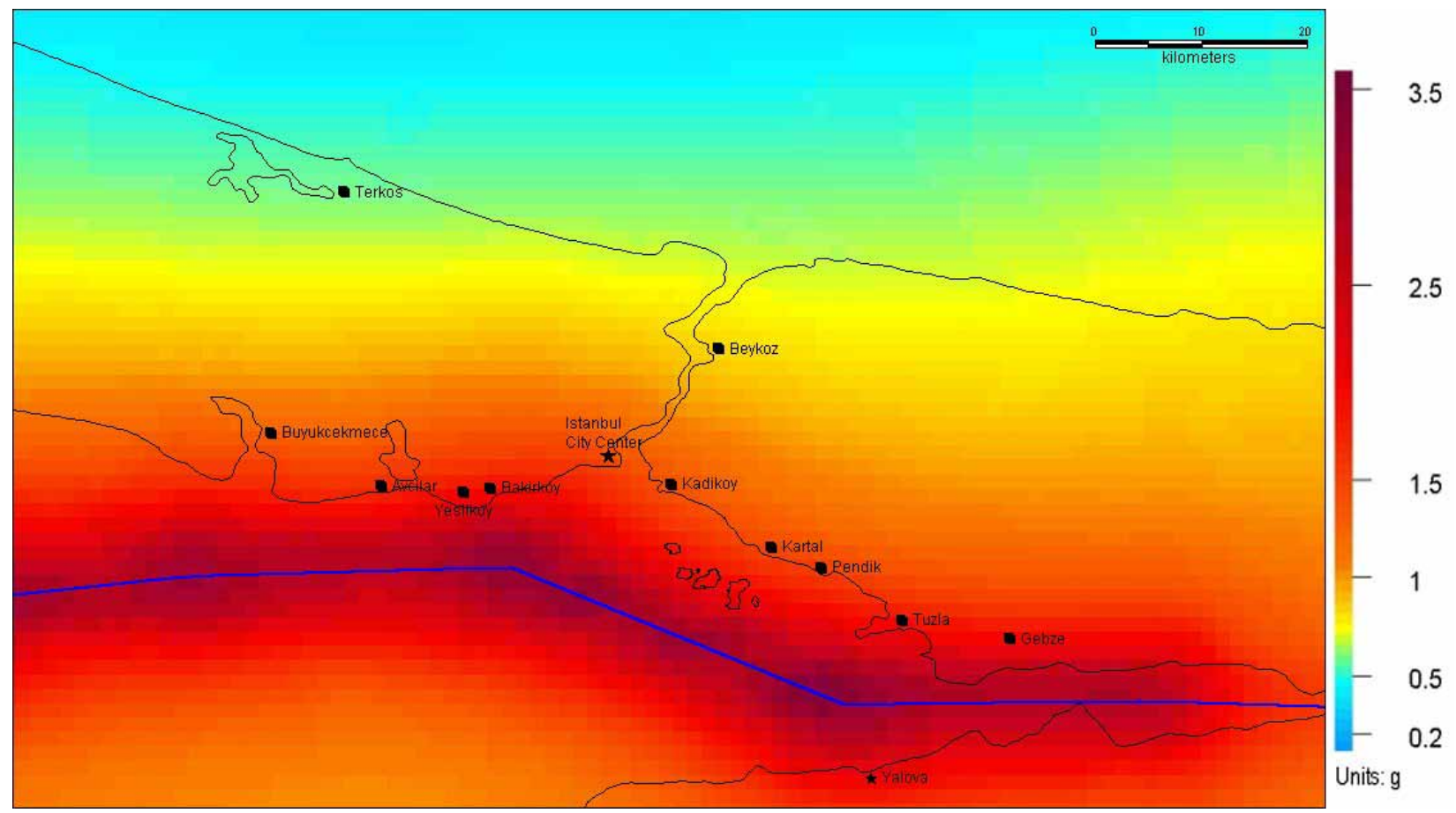

Figure 13. SA $(T=0.2 \mathrm{sec})$ contour map at NEHRP B/C boundary site class for $2 \%$ probability of exceedence in 50 years (Renewal model).

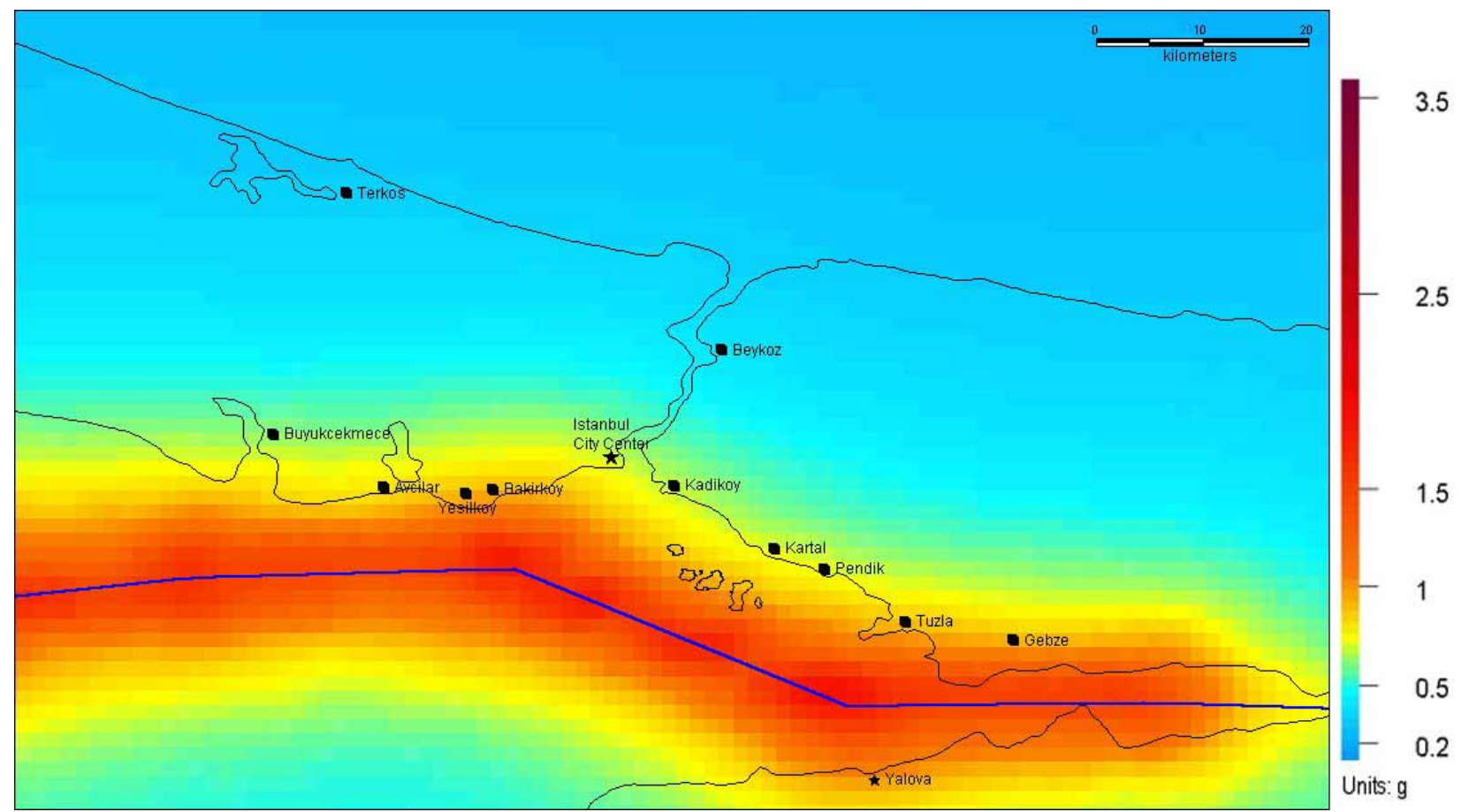

Figure 14. SA (T=1.0) contour map at NEHRP B/C boundary site class for $2 \%$ probability of exceedence in 50 years (Renewal model).

\section{DISCUSSION}


Comparison of different models utilized in the assessment of earthquake hazard is of both academic and practical concern. In this study earthquake hazard in the Marmara region is estimated by the Poisson and time-dependent (renewal) models using a fault segmentation model, that is compatible with recent findings. Both models assume that the segments rupture independently. The possibility, that an event ruptures several fault segments (i.e. cascading), is taken into account by the cascading methodology as described by Cramer [41]. In this methodology fault segments that are likely to rupture together form groups, which effectively means that a group becomes a single segment. The segment probabilities are adjusted in such a way that by keeping the total moment rate constant, the probabilities of multi-segment ruptures within that group are maximized. Other segments in the model that do not produce cascading are assumed to rupture independently. Two cascade models are considered. In cascade model I, three segment groups are considered to rupture together: 1-2-3-4, 5-6-7 and 8-9-10. In cascade model II there are five groups: 1-2, 3-4, 5-6, 7-8 and 9-10. The segments that are considered for cascading can be seen in Figure 2. The effect of cascading generally increases the earthquake hazard by about $10-20 \%$ depending on the site location.

The effect of the earthquake activity that took place in the $20^{\text {th }}$ century in the Marmara region is reflected in Figure 15, where Poisson and time-dependent models are compared, by decreased probabilities of earthquake occurrences in the areas hit by the 1999 Kocaeli and Düzce earthquakes and increased probabilities for Istanbul and the Marmara Sea region in general. In the Istanbul region where no major of earthquake occured for more than two centuries the time dependent analysis yields hazard results 1.1 to 1.3 times those of the Poisson analysis. On the other hand, for the Izmit region where a very recent major earthquake has taken place, time dependent accelerations fall about $50 \%$ below the Poisson accelerations.
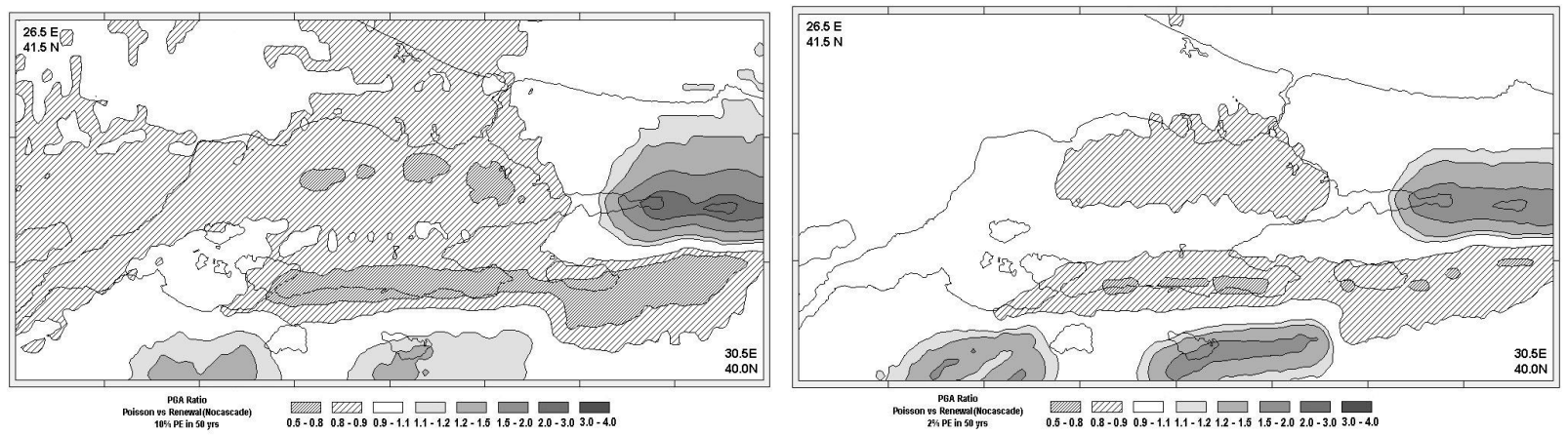

Figure 15. Ratio of Poisson to Renewal model (PGA, at NEHRP B/C boundary site class for 10\% probability of exceedence in 50 years and 2 probability of exceedence in 50 years)

\section{REFERENCES}

1. Frankel, A.D., C.Mueller, T.Barnhard, D.Perkins, E.Leyendecker, N.Dickman, S.Hanson and M.Hopper, "National Seismic Hazard Maps: Documentation June 1996”, USGS Open File Report 96-532, 1996.

2. Atakan, Kuvvet; Ojeda, Anibal; Meghraoui, Mustapha; Barka, Aykut A.; Erdik, Mustafa; Bodare, Anders, "Seismic Hazard in Istanbul following the 17 August 1999 Izmit and 12 November 1999 Duzce Earthquakes",BSSA vol:92 no:1,pp:466-482, 2002.

3. Erdik, M., Doyuran, V., Akkas, P. and Gulkan, P., "Assessment of the Earthquake Hazard in Turkey and Neighboring Regions", Tectonophysics 117, 295-344, 1985.

4. Erdik,M., Y.Alpay Biro, T.Onur, K.Sesetyan, and G.Birgören, "Assessment of earthquake hazard in Turkey and neighbouring regions", Annali di Geofisica, Vol.42, N0.6, 1125-1138, 1999.

5. Erdik,M, Y Biro, T Onur, K sesetyan and G. birgoren”, Assessment of earthquake hazard in Turkey and neighboring regions" Annali Di Geofisica, Vol. 42 N.6, pp. 1125-1138, 1999. 
6. Jimenez, M., D.Giardini, G.Grunthal, M.Erdik, M.Garcia-Fernandez, J.Lapajne, K.Makropoulos, R.Musson, Ch. Papaioannou, A.Rebez, S.Riad, S.Sellami, A.Shapira, D.Slejko, T. van Eck, A.El Sayed, "Unified Seismic Hazard Modeling Throughout The Mediterranean Region”, Bollet'no di Geofisica Teorica ed Applicata, 42: pp.3-18, Mar-June 2001.

7. Bommer, J., R.Spence, M.Erdik, S.Tabuchi, N.Aydinoglu, E.Booth, D. del Re, O.Peterken, "Development Of And Earthquake Loss Model For Turkish Catastrophe Insurance", Journal of Seismology, 6: 431-466, 2002.

8. Le Pichon, X., T. Taymaz and A.M.C. Sengör, "The Marmara Fault and the future Istanbul earthquake, in: International Conference on the Kocaeli earthquake, 17 August 1999", M. Karaca and D.N. Ural, eds., pp. 41-54, Istanbul Technical University Press House, Istanbul, 1999.

9. Le Pichon, X, A.M.C. Sengör, E. Demirbag, C. Rangin, C. Imren, R. Armijo, N. Görür, N. Çagatay, B. Mercier de Lepinay, B. Meyer, R. Saatçilar and B. Tok, "The Active Main Marmara Fault", Earth and Planetary Science Letters, Vol. 192 (4) pp. 595-616, 2001.

10. Barka A. A. and K. Kadinsky-Cade, , "Strike-Slip Fault Geometry in Turkey and its influence on earthquake activity", Tectonics, Vol. 7, No. 3, pp: 663-684, 1988.

11. Saroğlu, F., O. Emre and I. Kuscu, "Active Fault Map of Turkey", Mineral Res. Explor. Inst. Turkey, 1992.

12. Akyuz, H. S., A. Barka, E. Altunel, R. Hartleb, G. Sunal, "Field Observations and Slip Distribution of the November 12, 1999 DüzceEarthquake (M=7.1), Bolu-Turkey", The 1999 Izmit and DüzceEarthquakes: Preliminary Results, A. Barka, O. Kozacı, S. Akyüz and E. Altunel, Istanbul Tech. Un. Press, Istanbul, pp. 61-70, 2000.

13. Yaltirak, C., "Tectonic evoluation of Marmara Sea and its surroundings", Marine Geology, pp.137, 2002.

14. Durukal E., Cimilli S., Erdik M., "Dynamic response of two historical monuments in Istanbul deduced from the recordings of Kocaeli and Duzce earthquakes", Bulletin of Seismological Society of America, 93 (2): 694-712, 2003.

15. Parsons, T., S. Toda, R. S. Stein, A. Barka and J. H. Dieterich, "Heightened odds of large earthquakes near Istanbul: An interaction-based probability calculation”, Science, 288, pp. 661$665,2000$.

16. Ambraseys, N. N. and C. F. Finkel, "Long-term seismicity of Istanbul and of the Marmara Sea region", Terra Nova, 3, pp: 527-539, 1991.

17. Ambraseys, N. and A.Jackson, "Seismicity of the Sea of Marmara (Turkey) Since 1500", Geophys. J. Int., 141, F1-F6, 2000.

18. Erdik. M., "Report on 1999 Kocaeli and Düzce(Turkey) Earthquakes", Proc. Of the 3rd Intl. Workshop on Structural Control, Paris - France, 6-8 July 2000, p, 149-186, 2000.

19. Yagi, Y. and M. Kikuchi, "Source rupture process of the Kocaeli, Turkey, 1999 earthquake of August 17, 1999, obtained by joint inversion of near-field data and teleseismic data", Earthquake Research Institue, the University of Tokyo, 1999.

20. Hubert-Ferrari A., A. Barka, E. Jacques, S.N. Nalbant, B. Meyer, R. Armijo, P. Tapponier, and G.C.P. King, "Seismic Hazard in the Marmara Sea Region Following the 17 August 1999 İzmit Earthquake", Nature, Vol 404, 2000.

21. Rathje et al., "Strong ground motions and site effects, Chapter 4", Earthquake Spectra, vol. 16, supplement A, 2000.

22. Safak, E. and M.Erdik (Coordinators), "Recorded Main Shock and Aftershock Motions", Earthquake Spectra, Supplement A to Volume 16, 97-112, 2000.

23. Anderson, J., H. Sucuoglu, A. Erberik, T.Yilmaz, E.Inan, E.Durukal, M.Erdik, R.Anooshehpoor, J. Brune and S. Ni, "Strong Ground Motions from the Kocaeli and Düzce, Turkey, Earthquakes, and Possible Implications for Seismic Hazard Analysis", Earthquake Spectra, Supplement A to Volume 16, 113-137, 2000. 
24. Erdik, M. and Durukal, E., "1999 Kocaeli and Duzce, Turkey earthquakes: strong ground motion, XV ICSMGE TC4 'Lessons learned from recent strong earthquakes', 25 August 2001”, Istanbul, Turkey, 2001.

25. Durukal E., "Critical Evaluation of Strong Motion in Kocaeli and Düzce (Turkey) Earthquakes", Soil Dynamics and Earthquake Engineering 22, 589-609, 2002.

26. Delouis B., D. Giardini, P. Lundgren and J. Salichon, "Joint Inversion of InSAR, GPS, Telseismic and Strong-Motion Data for Spatial and Temporal Distribution of Earthquake Slip", Bulletin of Seismological Society of America, 92 (1): 278-299, 2002.

27. Bouchon M., M.N. Toksöz, H. Karabulut, M-P. Bouin, M. Dietrich, M. Aktar and M. Edie, "Space and Time Evolution of Rupture and Faulting during the 1999 İzmit (Turkey) Earthquake", Bulletin of Seismological Society of America, 92 (1): 256-266, 2002.

28. Joyner, W. B., and D. M. Boore, "Peak Acceleration and Velocity from Strong Motion Records Including Records from the 1979 Imperial Valley, California, Earthquake”, Bull. Seismol. Soc. Am., 71, pp. 2011-2038, 1981.

29. Erdik, M., E. Durukal and K. Sadetoğlu, "Empirical Response Spectra, Proceedings of the Third National Earthquake Engineering Conference (in Turkish"), 27-31 March 1995, Istanbul Technical University, pp. 714-723, 1995.

30. TEFER , "Improvement of Natural Hazard Insurance And Disaster Funding Strategy in Turkey Project, Project Reports prepared for Willis-Cordis Inc. by Bogazici University, 2001.

31. Boore, D. M., W. B. Joyner, T. E. Fumal, "Equations for Estimating Horizontal Response Spectra and Peak Acceleration from Western North American Earthquakes: A Summary of Recent Work", Seismological Research Letters, Vol. 68, No. 1, pp. 128-153, 1997.

32. Sadigh, K.,C.Y.Chang,J.A.Egan, F. Makdisi, R.R.Youngs "Attenuation Relationships for Shallow Crustal Earthquakes Based on California Strong Motion Data", Seismological Research Letters, 68, pp. 180-189, 1997.

33. Campbell, K. W., "Empirical Near-Source Attenuation Relationships for Horizontal and Vertical Components of Peak Ground Acceleration, Peak Ground Velocity, and Pseudo-Absolute Acceleration Response Spectra", Seismological Research Letters, 68, January/February, 1997.

34. Leyendecker E.V., A.D. Frankel, and K.S. Ruskstales, "Seismic design parameters for use with the 2000 International building code, 2000 International Residental Code, 1997 NEHRP Seismic Design Provision and 1997 NEHRP Rehabilitation Guidelines", Earthquake Spectra, 2000.

35. Cornell C.A., "Engineering seismic risk analysis", Bull. Seis. Soc. Amer., 58, 1583-1906, 1968.

36. Global Seismic Hazard Program (GSHAP), http://seismo.ethz.ch/GSHAP, 1999.

37. Perkins, D.M., "Fuzzy Sources, Maximum Likelihood, and the New Methodology, in A Unified Approach to Probabilistic Risk Assessments for Earthquakes, Floods, Landslide and Volcanoes", USGS OFR 01-324, 2001.

38. Weichert, D., "Estimation of Earthquake Recurrence Parameters for Unequal Observation Periods for Different Magnitudes", Bull.Seism.Soc.Am., v.70, pp.1377-1356, 1980.

39. Wells, D. L., and K. J. Coppersmith, "Empirical relationships among magnitude, rupture length, rupture width, rupture area, and surface displacement”, Bull. Seism. Soc. Am., 84, pp. 974-1002, 1994.

40. WGCEP94, "Seismic Hazards in Southern California: Probable Earthquakes, 1994 to 2024”, Bull. Seism. Soc. Am. Vol. 85, pp. 379-439, 1995.

41. Cramer, C.H., M. D. Petersen, C. Tianqing, R. Toppozada and M. Reichle "A time-dependent probabilistic seismic hazard model for California" Bulletin of Seismological Society of America, 90 (1): 1-21, 2000. 